МУХАМЕТЗЯНОВА-ДУГГАЛ Регина Массаровна - доктор политических наук, главный научный сотрудник отдела религиоведения Института этнологических исследований им. Р.Г. Кузеева - обособленного структурного подразделения Уфимского федерального исследовательского центра РАН (450077, Россия, Республика Башкортостан, г. Уфа, ул. К. Маркса, 6; mdregm@yandex.ru)

\title{
ПОСТСОВЕТСКАЯ ДИНАМИКА РАЗВИТИЯ ОБЩЕНАЦИОНАЛЬНОЙ ИДЕОЛОГИИ В КОНТЕКСТЕ ДУХОВНОЙ БЕЗОПАСНОСТИ РОССИИ
}

Аннотация. В статье автор рассматривает динамику развития общенациональной идеологии в России на рубеже XX-XXI вв. и выделяет два этапа - деидеологизации и реидеологизации. Первый этап (конец 1980-х - начало 1990-х гг.), связанный с либеральным реформированием периода перестройки, характеризуется отрицанием необходимости какой-либо идеологии. Второй этап (середина 1990-х гг. - настоящее время) связан с начавшимся процессом поиска национальной идеи и ориентиров, консолидирующих общество. На данном этапе поиски национальной идеи стали во все большей мере опираться на ценности религиозных учений.

Ключевые слова: духовная безопасность, общенациональная идеология, религия, Россия

$\Pi$ роблема духовной безопасности продолжает быть одной из актуальных в современной России. Если ранее считалось, что безопасность - это защищенность общества от военной угрозы, охрана государственных границ, борьба с подрывной деятельностью враждебных групп и с инакомыслящими, то по мере разработки проблем безопасности это понятие стало включать в себя технологическую, экологическую, правовую, информационную, финансовую, а также социальную безопасность, от которой прямой выход на проблему духовной жизни. Через призму политологического подхода духовная безопасность определяется как способность личности, общества и государства сохранять и развивать позитивную созидательную духовность; состояние защищенности жизненно важных духовных интересов и потребностей личности, общества и государства; система отношений между субъектами общественной жизни, обеспечивающая благоприятные условия для духовной жизни и духовного развития [Мухаметзянова-Дуггал 2015: 22].

В развитии общенациональной идеологии в России на рубеже XX-XXI вв. выделяются 2 этапа: деидеологизация (конец 1980-х - начало 1990-х гг.) и реидеологизация (середина 1990-х гг. - настоящее время). Первый этап связан с либеральным реформированием периода перестройки и деидеологизацией общественного сознания. Отказ от прежней модели государственного устройства, поиск нового курса политического и социально-экономического развития привели к переходу бывшего советского общества в новое качественное состояние. Кардинальные трансформации охватили все сферы жизнедеятельности общества, в частности духовную жизнь, психологию людей, на которые оказали свое воздействие политическая нестабильность, ухудшение экономического и экологического положения, межэтнические конфликты. Люди в поисках надежных социальных ориентиров стали обращаться в т.ч. к авторитету религии. В результате радикальных изменений во всех сферах жизни в обществе произошел отказ от идеалов и ценностных ориентиров, которыми три четверти века руководствовалось общество.

Конституции советской эпохи не допускали плюрализма в области идеологии. Принятая в 1977 г. Конституция СССР законодательно закрепляла руко- 
водящую и направляющую роль Коммунистической партии Советского Союза, объявленной ведущей силой общества. После распада Советского Союза и краха коммунистической идеологии в обществе образовался идеологический вакуум. Этот идеологический вакуум начал заполняться в т.ч. религиозными учениями. В этот переломный момент люди потянулись в церкви, мечети, начали изучать религиозную литературу. Увеличилось число зарегистрированных религиозных организаций. На наш взгляд, данный процесс был закономерным, т.к. изменение навязанной насильно ценностной ориентации - это вполне естественный процесс для любого возрождающегося общества.

После долгого периода критики коммунистической идеологии, отрицания необходимости какой-либо идеологии наметился второй этап в развитии общероссийской идеологии. Так, с середины 1990-х гг. начали говорить о необходимости государственной, национальной идеи, о выработке идейных ориентиров, консолидирующих общество.

На сегодняшний день выделяются две основные точки зрения на идеологию. Ряд исследователей выступают за выработку и принятие общенациональной, государственной идеологии. Они полагают, что современное российское общество испытывает идеологический дефицит и нуждается в создании идеологической системы, которая нацелит граждан на решение общих проблем [Беспаленко 2009; Кузнецов 2005]. Далеко не все поддерживают данную точку зрения. Противники государственной идеологии утверждают, что в обществе, основанном на принципах политического и идейного плюрализма, никакой идеологии, претендующей на роль государственной, быть не должно [Чудинова 1999; Формирование новой... 2000: 28], тем более что об этом сказано в ст. 13 Конституции РФ. По мнению ряда ученых, сама постановка вопроса о формировании новой идеологии - это реликт тоталитарного режима, попытка взять курс на идеологическое манипулирование общественным сознанием россиян. Часть авторов предлагают уйти от однозначно негативного отношения к идеологии и рациональное решение проблемы видят в поощрении идеологического плюрализма, создании условий для сосуществования разных концепций и взглядов [Рубцов 2016; 2018; Шилов 2015].

Не ставя в рамках данной статьи задачу проанализировать все идейные тенденции и современные концепции пути развития России, рассмотрим участие религиозных структур в процессе поиска общенациональной идеологии. Как показал анализ нормативно-правовой базы, а также научной литературы, к концу 1990-х гг. поиски национальной идеи стали во все большей мере опираться на ценности и инфраструктуру христианских, исламских и других религиозных учений. Естественно, что в условиях духовного и религиозного возрождения возникли потребность и возможность сотрудничества традиционных религиозных организаций и государственных структур, политической элиты в целях поиска и закрепления национальной идеи, способной интегрировать российское общество. В подобных условиях, по мнению М.П. Мчедлова, которое представляется нам справедливым, необходимо было учитывать религиозные ценности и ориентиры, предлагаемые религиозными организациями, имеющими для этого цельное мировоззрение и проверенные веками гуманистические принципы человеческого общежития [Мчедлов 1993: 61].

В то же время необходимо реально оценивать возможности религии и религиозных организаций в содействовии социальному и нравственному возрождению страны. В современном российском обществе и в сфере политического истеблишмента пока не сложилось единое представление о месте и роли религии в общественном развитии. Приверженцы конституционных норм в сфере 
свободы совести по-прежнему пытаются сохранить в стране либерально-демократическое отношение к религии; сторонники возвращения к национальнокультурным традициям стремятся выстроить идеологию государственного развития на базе традиционных религиозных ценностей [Mukhametzyanova-Duggal 2018: 56]. По нашему мнению, не совсем верно то, что государство продолжает связывать поиск национальной идеи, на которую возлагается надежда по выходу из кризиса, только с религиозными конфессиями. Такой подход подрывает принципы отделения религиозных объединений от государства, лежащие в основе современной организации общества. Необходимо также учитывать, что, по данным социологических опросов, около $50 \%$ населения России не считают себя последователями какой-либо религии, вероисповедания [Кофанова, Мчедлова 2010: 201]. Государственным органам власти правильнее, на наш взгляд, ориентироваться на общие усилия, посильный вклад и сотрудничество всех учреждений и движений, способных на социально полезные и патриотические деяния, а также на удовлетворение разносторонних духовных потребностей человека.

Важно, что общенациональная идеология должна способствовать укреплению духовной безопасности и создавать основы для консолидации всех общественных сил. По содержанию она должна составлять квинтэссенцию духовных ценностей россиян, соответствовать национальным традициям, быть адекватной требованиям эпохи. По мнению Ж.Т. Тощенко, современная идеология должна быть «многомерной», т.е. полноценно отражать интересы разных слоев общества, учитывать все этнокультурное и конфессиональное многообразие России. Только в этом случае она сможет стать основой национальной самоидентификации россиян [Тощенко 2007: 50].

Таким образом, государственным структурам для обеспечения духовной безопасности России, на наш взгляд, необходимо занять такую позицию по отношению к традиционным религиям, в которой поддержка и уважение сочетались бы со стремлением провести четкую границу между религиозными структурами и светской государственностью, религиозными учениями и общенациональной идеологией. Тем более что традиционных религий в нашей стране несколько, и идеологизация мировоззрения одной из них может привести к обострению межконфессиональных и межэтнических отношений. В то же время является недопустимой и политика целенаправленного свертывания любых форм сотрудничества государства и религиозных объединений, если имеется положительный опыт совместного решения социальных проблем.

\section{Список литературы}

Беспаленко П.Н. 2009. Духовная безопасность в системе национальной безопасности современной России: проблемы институционализации и модели решения: дис. ... д.полит.н. Ростов н/Д. 250 с.

Кофанова Е.Н., Мчедлова М.М. 2010. Религиозность россиян и европейцев. - Мониторинг общественного мнения. № 4(98). С. 201-230. Доступ: https://wciom. $\mathrm{ru} /$ fileadmin/file/monitoring/2010/96/2010_2(96)_10_Kofanjva.pdf (проверено 27.10.2018).

Кузнецов В. 2005. Идеология. Социологический аспект. М.: Книга и бизнес. 816 с.

Мухаметзянова-Дуггал Р.М. 2015. Духовная безопасность в современном российском обществе: некоторые теоретические и практические аспекты. Проблемы востоковедения. № 4(70). С. 22-26.

Мчедлов М.П. 1993. Религиозная ситуация в России: реалии, противоречия, прогнозы. - Свободная мысль. № 5. 
Рубцов А.В. 2016. Практическая идеология. К аналитике идеологических проиессов в политической и социокультурной реальности. М.: ИФ РАН. 246 с.

Рубцов А.В. 2018. Превращения идеологии. Понятие идеологического в «предельном» расширении. - Вопросы философии. № 7. С. 18-27.

Тощенко Ж.Т. 2007. Теократия: фантом или реальность. М.: Academia. 664 c.

Формирование новой российской идеологии: материалы круглого стола. 2000. - Свободная мысль - ХХІ в. № 3.

Чудинова И.М. 1999. Идеология и политика. - Социально-гуманитарные знания. № 4. С. 122-134.

Шилов В.Н. 2015. Идеология для современной России: необходимость и предпосылки. - Научные ведомости. Сер. История. Политология. № 7. С. 183-189.

Mukhametzyanova-Duggal R.M. 2018. World Outlook and Institutional Foundations of State Confessional Policy in Modern Russia. - Journal for the Study of Religions and Ideologies. Vol. 17. Iss. 51. Winter. P. 53-68.

MUKHAMetzYANOVA-DUGGal Regina Massarova, Dr.Sci. (Pol.Sci.), Chief Researcher of the Department of Religious Studies, R.G. Kuseev Institute for Ethnological Studies - subdivision of Ufa Federal Research Center of the Russian Academy of Sciences (6 Karla Marksa St, Ufa, Republic of Bashkortostan, Russia, 450077; mdregm@yandex.ru)

\section{POST-SOVIET DYNAMICS OF THE DEVELOPMENT OF NATIONAL IDEOLOGY IN THE CONTEXT OF SPIRITUAL SAFETY OF RUSSIA}

\footnotetext{
Abstract. The article considers dynamics of the development of the national ideology in Russia at the turn of the $20^{\text {th }}-21^{\text {st }}$ centuries. The author distinguishes two stages of this process - that is deideologization and reideologization of public consciousness. The first stage (late 1980s - early 1990s), associated with the liberal reform of the period of restructuring ( "perestroika»), is characterized by criticism of Communist ideology, denial of the need for any ideology. The second stage (mid-1990s - present time) is associated with the process of searching for a national idea and guidelines that consolidate society. By the end of the 1990s, the search for a national idea was increasingly based on the values of religious teachings. The author believes that this approach contradicts the principle of separation of religious institutions from the state and it seems necessary to focus on the common efforts of all institutions capable of socially useful activities.

Keywords: spiritual security, national ideology, religion, Russia
} 